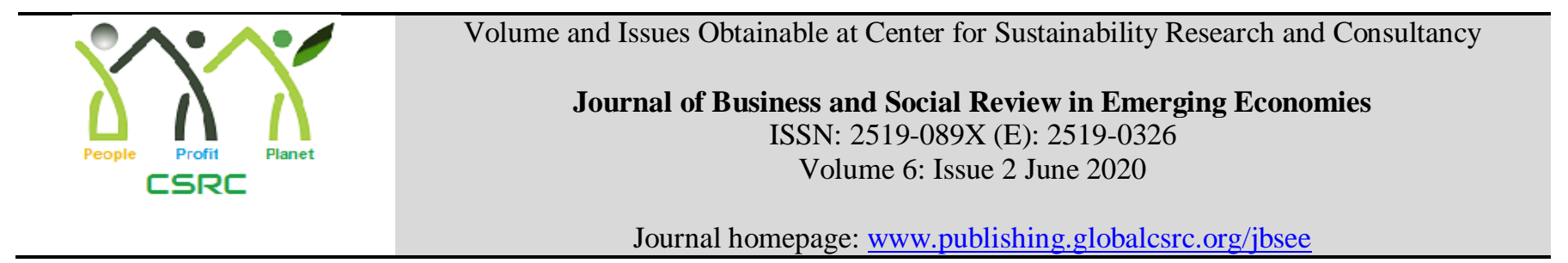

\title{
Factors Affecting Bankers' Behavioral Intention to Adopt Green Banking: An Empirical Analysis of Banks in Pakistan
}

\section{${ }^{1}$ Owais Shafique, ${ }^{2}$ Maryam Khan}

${ }^{1}$ Assistant Professor, School of Business, Management and Administrative Sciences, The Islamia University of Bahawalpur, Pakistan, dr.owais.shafique@gmail.com

${ }^{2}$ MS Scholar, School of Business, Management and Administrative Sciences, The Islamia University of Bahawalpur, Pakistan

\section{ARTICLE DETAILS}

\section{History}

Revised format: May 2019

Available Online: June 2020

\section{Keywords}

Behavioral Intention, Green

Banking, Pakistan, Banks

JEL Classification

MO, M1

\begin{abstract}
The global temperature has reached its highest level since the start of the industrial revolution, which is the major cause of global warming. Global warming has become one of the gravest problem now a days as it has considerable influences over markets, societies and economies. For sustainable environment management, remarkable efforts are carried out across the world and every institution is playing its role towards minimizing its impact on the environment. From financial institutions, banking sector is playing an important role in this regard. Banking sector has introduced a concept of Green Banking (GB). State Bank of Pakistan (SBP) has recently issued guidelines regarding the adoption of green banking. This study attempts to identify the factors which affect bankers' intension to adopt green banking. This study would prove to be helpful in identifying the most influencing factors towards adoption of green banking practices and in developing policies towards its adoption in Pakistan. Structured questionnaire based on a 7 point Likert scale as used for data collection from a sample of 300 respondents. Regression analysis was used to check the association among the variables. The result of study shows that all independent variables of study have shown significant association with dependent variable. Which means to some extent every independent factor is playing role in affecting bankers' behavioral intention to adopt green banking. Result shows that perceived usefulness and perceived ease of use contribute more in predicting the Attitude toward use, which along with effort expectancy and performance expectancy are major contributing factors towards behavioral intention to adopt green banking practices.
\end{abstract}

(C) 2020 The authors, under a Creative Commons AttributionNonCommercial 4.0

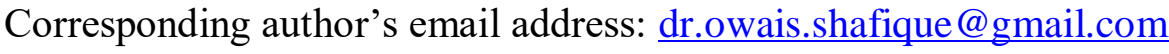

Recommended citation: Shafique, O., Khan, M., (2020). Factors Affecting Bankers' Behavioral Intention to Adopt Green Banking: An Empirical Analysis of Banks in Pakistan. Journal of Business and Social Review in Emerging Economies, 6(2), 835-843

\section{Introduction}

Global Warming is hot issue now a days and has had adverse effect on global climate (BB Green Banking policy, 2012). It also poses a considerable influence over markets, societies and economies (EBF Report, 2017). Climatic changes 
prove alarming for essential constituents of human life i.e. production of food, availability of water, health, usability of land and environment. Climatic changes and environmental risks are evidenced as having important and unavoidable implications for financial stability through out the world (BB Green Banking policy, 2012).

Increased levels of greenhouse gasses have disrupted global weather and climate patterns which has resulted in a swift global response by most governments and the United Nations. In this situation, business are instantly under intense pressure fro consumers and stakeholders to play their part in protecting the planet by making their operations and activities more sustainable (BB Green Banking policy, 2012). For sustainable environment management, remarkable efforts are being carried out across the world (Cogan, 2008). Best sustainable development and environmental management practices are observed in UK, US, Japan and Singapore. Moreover, the greatest practice in this direction is to go 'green' (Chua \& Oh, 2011).

'Green' means a wide range of environmental, social and ethical dimensions (Ullah, 2013). Government authorities, direct emitters, stakeholders and financial institutions must also play their important role in environment protection (Jha \& Bhome, 2013). Since, the banking sector is a sector which gives loan in different sectors, therefore, it can play a crucial role towards environmental sustainability (Meena, 2013). Through investment and CSR activities banks play important role in saving the environment. Through financing activities of banks, banks hold a unique position in an economic system which can affect businesses, productions and other economic activities. (AUBHI, 2016).

The banking sector, all over the world, has introduced the concept of green banking to address environmental concerns. If banks adopt green banking practices in their financing and investment operations, they can better serve their clients (Ghosh et al., 2018). Green refers to environmental performances and environmental accountability in business activities (Bai, 2011). So Green Banking is a form of banking which takes in consideration of environmental activities and protects environment (Goyal \& Joshi, 2011; Habib, 2010).

The basic goal of GB is the protection of the natural resources of the planet (Lalon, 2015). GB uses natural resources efficiently, effectively and responsibility and strives to minimize wastage of resources and harmful emissions. GB needs financial institutions to support projects that take sustainability, efficient production and waste minimization into consideration (Biswas, 2011).

The developed countries, as well as some developing countries, have already adopted green banking and have made sufficient contribution towards environment sustainability. However, green banking is still unusual and not commonly practiced in Pakistan, because adoption of green banking is complex in Pakistan (Kandavel, 2013). However, in order to be environmentally sustainable, Pakistan needs to put its best efforts towards the adoption of green banking and financing (Samad \& Manzoor, 2011). In 2017, the State Bank of Pakistan (SBP) issued green banking guidelines which were to be implemented voluntarily by all banks within a year as per the directions of SBP, however, green banking has not been fully implemented in any bank even after three years. Whereas, several other developing countries, such as Bangladesh, have been very quick in adopting green banking practices. As green banking is gaining momentum throughout the world, the aim of this study is to reveal the factor that affects bankers 'intension to adopt GB practices in Pakistan.

GB implementation can not be achieved unless the users are not motivated to adopt these practices and in turn the organization will also not be able to reap the benefits of GB (Al-Smadi, 2012). Hence, it is important to recognize the variables which affect the adoption and acceptance of GB practices (Al-Smadi, 2012). This study strives to identify the factors that affect bankers 'intention to adopt GB practices. This study would prove to be helpful for banks in Pakistan to adopt GB practices. This study would prove to be helpful for SBP to improve their policies and regulations regarding green banking implementation.

This study will investigate whether Perceived Usefulness (PU) and Perceived Ease of Use (PEU) affect bankers' Attitude Towards Use (ATU). The study will also study whether ATU, Effort Expectancy (EE) and Performance Expectancy (PE) influence bankers' behavioural intension to adopt green banking practices. 


\section{Literature Review}

Sustainable development of many countries is hindered by over dependence and over utilization of the earth's natural resources (World energy outlook, 2009). If the usage of fossil fuels remains the same as currently it is, temperature will proportionally rise by 4-6 degrees Celsius which would be disastrous for human health, biodiversity and communities' survival (Sachs, Woo, Yoshino, \& Taghizadeh-Hesary, 2019). Throughout the world, Governments have started working on development of balanced economy, which means an economy without negative environmental impacts (Ahmad, Zayed, \& Harun, 2013).

Green finance basically is an environmentally friendly combination of business and finance. It includes many participants such as: individuals, business investors, financial lenders, consumers, producers (Wang \& Zhia, 2016). Sustainable investment and banking serve as key element to GF where environmental screening and risk assessment are basics for investments and lending decisions to fulfill the standards of environmental sustainability (Böhnke $e t$ al., 2014).

Green banking allows banks to mobilize money, safe investments, and spend money in productive activities without deteriorating the environment and living standards. It promotes as well as facilitates achieving the sustainable development of banking and finance (Goyal \& Joshi, 2011; Sahoo \& Nayak, 2007).

Pakistan needs to put its best efforts towards the adoption of green banking to reap its timely rewards (Samad \& Manzoor, 2011). There are several factors which affect bankr's behavioral intention to adopt green banking practices in Pakistan.

An extensive literature review reveals that Perceived Ease of Use (PEU) is an important factor which affects user intention to adopt green banking services; for example, Lu, Yu, Liu, and Yao (2003), Morteza, Aranda and Amado (2011) and Baraghani (2008) revealed positive association through the use of wireless internet, e-commerce and internet banking, respectively. According to Davis, (1989) PEU means to evaluate the mental effort required by potential users for the use of the new applications. If other conditions remain same, those applications are more acceptable which are comparatively easy to use (Baraghani, 2008). Numerous studies cover that PEU is a significant factor which influences bankers' behavioral intention to adopt green banking practices.

Hence, hypothesis $\mathbf{1}$ is: PEU significantly affects bankers 'ATU.

Perceived usefulness (PU) is another important factor which defines the potential user's subjective probability that using green banking service improves operations (Lu et al., 2003). The study claims that PU is an important constituent among the factors responsible for the adoption green banking Practices. According to Lu et al., (2003) PU means improving banking operations by using green banking practices from the perspective of the prospective user's subjectivity.

Hence, hypothesis 2 is: PU significantly affects bankers 'ATU.

Literature review further reveals that both PU and PEU have a significant and positive impact on the attitude towards use which intern leads to behavioral intention to adopt green banking. Hence, another important factor that influences the adoption of green banking is attitude towards use. Attitude Towards Use (ATU) explains the user's favorable or unfavorable assessment regarding the behavior in question (Davis, 1989). Literature reveals that the users will only adopt green banking practices if ATU is positive. Aboelmaged and Gebba (2013), Khanifar (2012) and Medyawati, Christiyanti, and Yunanto (2011) reveled that there is a positive relationship between ATU and BIAGB.

Hence, hypothesis 3 is: ATU significantly affects bankers 'BIAGB.

Effort Expectancy (EE) is usually associated with the ease of using a specific technology in specific working conditions (Phichitchaisopa \& Naenna, 2013). EE means that the user of a technology realizes that using that particular technology will be free of effort. Alwahaishi and Snasel, (2013), Nisha, Idrish and Hossain (2015), Afshan and Sharif (2016) and Chaouali, Yahia and Souiden (2016) uncover that EE is a key factor in the adoption of technology-based services. The effort needed to use green banking services is incontrovertibly climacteric for the employees because GB will constitute a significant portion of the working environment. Therefore, the employees will evaluate the time and effort they have to exert to use GB technologies (Venkatesh, Thong, \& Xin, 2012). 
Hence, hypothesis 4 is: EE significantly affects bankers 'BIAGB.

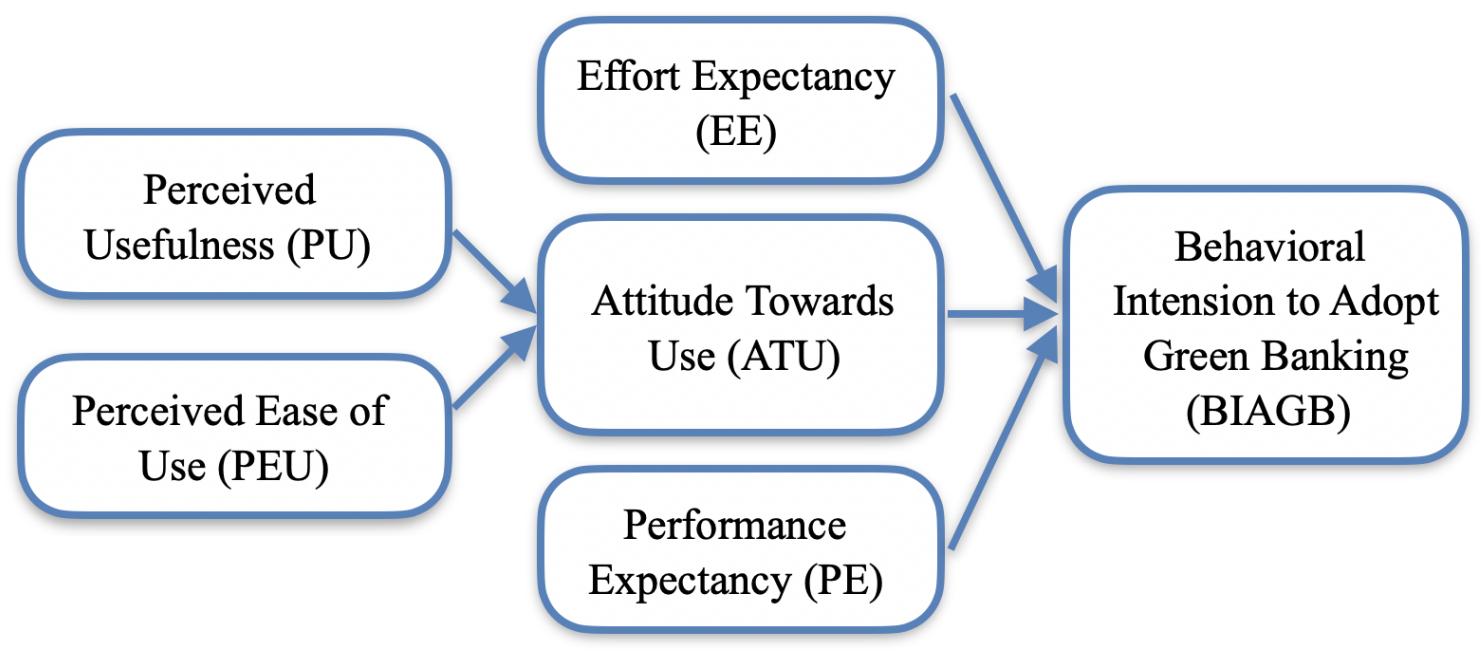

Performance Expectancy (PE) means how extensively does an employee / user believes that his/her job performance will be enhanced through the use of a particular technology (Algharibi \& Arvanitis, 2011). Hence, PE is the perception of the employees that whether they an achieve efficiency and effectiveness in their routine activities through the use of green baking practices. A thorough literature review suggests that PE might be the most important factor and the most powerful predictor for the adoption of technology-based service. Alwahaishi and Snasel (2013). Afshan and Sharif (2016), Chaouali et al. (2016) and Malaquias and Hwang (2016) assert that the efficacy of GB services might only be assessed through its ability to fulfill the expectations of the employees. Therefore, the employees are much more likely to adopt green banking practices if they feel that it will allow them to work quickly and effortlessly.

Hence, hypothesis 5 is: PE significantly affects bankers 'BIAGB.

Figure 1 shoes the theoretical framework developed after a through literature review and Table 1 shows the sources of conceptual framework. At first, PU and PEU have been studied for their impact on ATU. Then ATU along with effort expectancy and performance expectancy are studied for their impact on BIAGB.

Figure 1: Theoretical Framework

\begin{tabular}{|c|c|}
\hline \multicolumn{2}{|c|}{ Table 1: Sources of Conceptual Framework } \\
\hline Variables & Sources \\
\hline Perceived Usefulness (PU) & $\begin{array}{c}\text { (Nath, Nayak, \& Goel, 2014), (Morteza } \text { et al., 2011), } \\
\text { (Al-Smadi, 2012) }\end{array}$ \\
\hline Perceived Ease of Use(PEU) & $\begin{array}{c}\text { (Nath } \text { et al., 2014), (Morteza } \text { et al., 2011), (Baraghani, } \\
\text { 2008), (Lu } \text { et al., 2003) }\end{array}$ \\
\hline Attitude Towards Use (ATU) & $\begin{array}{c}\text { (Nath } \text { et al., 2014), (Medyawati } \text { et al., 2011), } \\
\text { (Aboelmaged \& Gebba, 2013), (Khanifar, 2012) }\end{array}$ \\
\hline Effort Expectancy (EE) & (Rifat, Nisha, Iqbal, \& Suviitawat, 2016) \\
\hline Performance Expectancy (PE) & (Rifat et al., 2016) \\
\hline
\end{tabular}




\section{Methodology}

This is an empirical research. A questionnaire survey method has been used to collect data and to serve this purpose a structured questionnaire has been used. The questionnaire for this study was developed in English. The questionnaire was adapted through detail analysis of various studies identified in Tale 1. To avoid the issue of central tendency this questionnaire adopts a 7-point Likert scale, to access the factor affecting bankers 'BIAGB.

As this study is an empirical analysis of banks in Pakistan so banks in Pakistan were the target population for this study. All male and female employees in banks were targeted. This study settled on a sample size of 300 respondents for data collection. This sample size of 300 was chosen because Comrey and Lee (2013) claim that 300 is a good sample. The data was collected through the use of cluster sampling technique which is a type of probability sampling.

\section{Data Analysis}

Profile of the 300 respondents is presented in Table 2.

\begin{tabular}{|l|c|c|}
\hline \multicolumn{3}{|c|}{ Table 2: Profile of Respondents } \\
\hline Demographis & Frequency & Percentage \\
\hline Gender & & \\
\hline Male & 215 & $71.7 \%$ \\
\hline Female & 85 & $29.7 \%$ \\
\hline Total & 300 & $100 \%$ \\
\hline Age & & \\
\hline $21-30$ & 71 & $23.7 \%$ \\
\hline $31-40$ & 118 & $39.3 \%$ \\
\hline Above 40 & 111 & $37 \%$ \\
\hline Total & 300 & 100 \\
\hline Qualifiation & & \\
\hline Undergraduate & 160 & $53.3 \%$ \\
\hline Post-Graduation & 140 & $46.7 \%$ \\
\hline Total & 300 & 100 \\
\hline
\end{tabular}


Cronbach's Alpha is used to measure the inter-item consistency of measures in order to access the reliability of scale. The Cronbach's Alpha score for all the variables in the study is .972 which is far above the acceptance standard of .70, therefore, it conforms the inter-item consistency of measures.

\begin{tabular}{|l|l|l|l|l|}
\hline \multicolumn{5}{|c|}{ Table 3: Model Summary } \\
\hline Model & R & R Square & Adjusted R Square & Std. Error of the Estimate \\
\hline PEU & .720 & 0.368 & 0.367 & 0.83346 \\
\hline PU & .720 & 0.518 & 0.515 & 0.82346 \\
\hline AU & .770 & 0.592 & 0.591 & 0.76249 \\
\hline EE & .855 & 0.73 & 0.727 & 0.62326 \\
\hline PE & .879 & 0.773 & 0.770 & 0.57643 \\
\hline
\end{tabular}

Table 3 shows the model summary. The value of $\mathrm{R}$ represent the relationship of dependent variable with independent variables. The value of $\mathrm{R}$ for all variables is positive which means all variables have positive relationship with one another. The value of $\mathrm{R}^{2}$ represents what percent change in dependent variable is caused by $1 \%$ change in independent variables.

\begin{tabular}{|c|c|c|c|c|c|c|}
\hline \multicolumn{7}{|c|}{ Table 4: Regression Analysis } \\
\hline Hypothesis & Model Variables & Beta $\beta$ & S.E. & $\mathrm{t}$ & P. Value & Result \\
\hline $\mathrm{H} 1$ & PEU $\rightarrow$ AU & 0.253 & 0.089 & 4.275 & 0.000 & Accepted \\
\hline H2 & PU $\rightarrow$ AU & 0.514 & 0.084 & 8.692 & 0.000 & Accepted \\
\hline H3 & AU $\rightarrow$ BIAGB & 0.086 & 0.044 & 1.981 & 0.049 & Accepted \\
\hline H4 & EE $\rightarrow$ BIAGB & 0.328 & 0.069 & 5.284 & 0.000 & Accepted \\
\hline H5 & PE $\rightarrow$ BIAGB & 0.275 & 0.065 & 5.107 & 0.000 & Accepted \\
\hline
\end{tabular}

Table 4 shows the results of the regression analysis. The value of $\beta$ shows the contribution of independent variables in predicting the dependent variable. $\mathrm{P}$ value shows the level of significance. If the value of $\mathrm{P}$ is less than 0.005 it means the independent variables have statistically significant impact on dependent variables.

The results presented in Table 4 shows that PEU and PU have a significant positive relationship with ATU, with $\beta=0.253$ and $\beta=0.514$, respectively, and $\mathrm{p}$ less than 0.05. It also shows that ATU, EE and PE have a significant positive relationship with BIAGB, with $\beta=0.086, \beta=0.328$ and $\beta=0.275$, respectively, and $p$ less than 0.05 . 


\begin{tabular}{|c|c|c|c|c|c|c|}
\hline \multicolumn{7}{|c|}{ Table 5: Anova } \\
\hline Hypothesis & Model Variables & df & M.S. & F & sig. & Result \\
\hline H1 & PEU $\rightarrow$ AU & 2 & 98.369 & 139.64 & 0.000 & Accepted \\
\hline H2 & PU $\rightarrow$ AU & 1 & 108.369 & 159.817 & 0.000 & Accepted \\
\hline H3 & AU $\rightarrow$ BIAGB & 8 & 40.303 & 114.433 & 0.000 & Accepted \\
\hline H4 & EE $\rightarrow$ BIAGB & 2 & 142.481 & 302.365 & 0.000 & Accepted \\
\hline H5 & PE $\rightarrow$ BIAGB & 1 & 241.758 & 422.553 & 0.000 & Accepted \\
\hline
\end{tabular}

Table 5 reveals that there is a statistically significant difference among groups as established by one-way ANOVA. All the hypothesis are accepted cause the significance value of $\mathrm{F}$ is below the maximum acceptable level of 0.050 .

\section{Conclusion}

This study was conducted to uncover the factors that affect behavioral intension of bankers 'to adopt green baking. Several factors were identified as independent variables. After checking the normality and reliability, regression analysis was conducted in order to reveal which variables are statistically significant. The result of study shows that all independent variables of study have shown significant association with dependent variable. Which means every independent factor is playing a role in affecting bankers 'behavioral intension to adopt green banking practicing to some extent.

The study reveals that Perceived Ease of Use (PEU) and Perceived Usefulness (PU) have a statistically significant positive relationship with Attitude Towards Use (ATU). Moreover, the study also unearthed that Attitude Towards Use (ATU), Effort Expectancy (EE) and Performance Expectancy (PE) have a statistically significant positive relationship with bankers' behavioral intension to adopt green banking (BIAGB) practices.

\section{Implications}

- This study identifies the factors which affect bankers 'intension to adopt green banking practices.

- This study would prove fruitful for the State bank of Pakistan in devising new policies and regulations regarding the implementation of green banking parties in Pakistan.

\section{Limitations}

- Data from the government, Islamic and commercial banks has not been studied separately to identify any differences among them.

- It was difficult to get data from the top management of banks as there was limited access to the top management of banks due to their time constraints.

- Financial constraint was also one of the major limitations as collecting data from the banks all over Pakistan requires lots of finance.

\section{Potential for Further Research}

- It is proposed that any future study must study the factors effecting the adoption of green banking practices among government, Islamic and commercial banks separately.

- It is proposed that any future study must study the level of adoption of green banking practices among government, Islamic and commercial banks of Pakistan. 
- It is proposed that any future study must study the impact of adoption of green banking practices on banks overall profitability.

\section{References}

Aboelmaged, M., \& Gebba, T. (2013). Mobile Banking Adoption: an Examination of Technology. International Journal of Business Research and Development, 2(1), 35-50.

Afshan, S. and Sharif, A. (2016) 'Acceptance of mobile banking framework in Pakistan', Telematics and Informatics, Vol. 33, No. 2, pp.370-387.

Ahmad, F., Zayed, N. M., \& Harun, M. A. (2013, july-December). Factors behind the Adoption of Green Banking by Bangladeshi Commercial Banks. ASA University Review, Vol. 7 No. 2.

Al-Smadi, M. (2012). Factors Affecting Adoption of Electronic Banking: an Analysis of The Perspectives of Banks' Customers. International Journal of Business and Social Science, 1-16.

Algharibi, A.J. and Arvanitis, T.N. (2011) 'Adapting the unified theory of acceptance and use of technology (UTAUT) as a tool for validating user needs on the implementation of e-trial software systems', Proceedings of the 25th BCS Conference on Human-Computer Interaction, 4-8 July, Newcastle-upon-Tyne, UK, pp.526530.

Alwahaishi, S. and Snasel, V. (2013) 'Acceptance and use of information and communications technology: a UTAUT and flow based theoretical model', Journal of Technology Management \& Innovation, Vol. 8, No. 2, pp.6173.

AUBHI, R. U. (2016). The Evaluation of Green Banking Practices in Bangladesh. Research Journal of Finance and Accounting, 7(7).

Bai, Y. (2011). Financing a green future Viewed: September. 15, 2012.

Baraghani, S. (2008). Factors Influencing the Adoption of Internet Banking.

BB Green Banking policy. (2012, july 21). Retrieved from : http://www.basicbanklimited.com/files/Green_Banking_Policy_Guidelines_of_Bangladesh_Bank.pdf

Biswas, N. (2011). Sustainable green banking approach: The need of the hour. Business Spectrum, 1(1), 32-38.

Böhnke, J., Eidt, V., Knierim, L., Richert, K., Röber, G., \& Volz, U. (2014). How to Make Green Finance WorkEmpirical Evidence from Bank and Company Surveys, German Development Institute / Deutsches Institut für Entwicklungspolitik (DIE). Retrieved from https://www.cbd.int/financial/gcf/definition-greenfinance.pdf

Chaouali, W., Yahia, I.B. and Souiden, N. (2016) 'The interplay of counter-conformity motivation, social influence and trust in customers' intention to adopt Internet banking services: the case of an emerging country', Journal of Retailing and Consumer Services, Vol. 28, pp.209-218.

Chua, S. C., \& Oh, T. H. (2011). Green progress and prospect in Malaysia. Renewable and Sustainable Energy Reviews, 15(6), 2850-2861.

Cogan, D. G. (2008). Corporate governance and climate change: The banking sector. New York: A Ceres Report, Risk Metrics Group Inc.

Comrey, \& Lee. (2013). A First Course in Factor Analysis. (Second ). Newyork, USA: Psychology Press.

Davis, F. (1989). Perceived Usefulness, Perceived Ease of Use, and Acceptance of Information Technology. Mis Quarterly, 13(3), 319-339.

EBF Report. (28 September 2017). Towards a Green Finance Framework. European Banking Federation .

Ghosh, S. K., Ghosh, P. K., \& Chowdhury, S. (2018). Essential of Central Bank's Regulatory Policy to Strengthen Green Banking Practice and Reporting in a Country. Asian Journal of Finance \& Accounting, Vol.10, No.2.

Goyal, K., \& Joshi, V. (2011). A study of social and ethical issues in banking industry. International Journal of Economics and Research, 2(5), 49-57.

Habib, S. (2010). Green Banking: A Multi-Stakeholder Endeavour. Retrieved from The Daily Star 07 August: <http://archive.thedailystar.net/newDesign/news-details.php?nid=149676>

Jha, N., \& Bhome, S. (2013). A study of green banking trends in India. International Monthly Referred Journal of Research in Management and Technology, 2, 127-132.

Kandavel, D. (2013). Green Banking Initiatives of the Commercial Banks in India. SIT Journal of Management, 3(2), 213-225.

Khanifar, E. (2012). Factors Influencing the Intendancy of E-Banking: an Integration of TAM \& TPB with Eservice. Journal of Applied Sciences Research, 842-1852. 
Lalon, R. M. (2015). Green banking: Going green. International Journal of Economics, finance and management sciences, 3(1), 34-42.

Lu, J., Yu, C., Liu, C., \& Yao, J. (2003). Technology Acceptance Model for Wireless Internet. Internet Re-Search: Electronic Networking Applications and Policy, 13(3), 206-222.

Malaquias, R.F. and Hwang, Y. (2016) 'An empirical study on trust in mobile banking: A developing country perspective', Computers in Human Behavior, Vol. 54, pp.453-461.

Medyawati, H., Christiyanti, M., \& Yunanto, M. (2011). E-Banking Adoption Analysis Using Technology Acceptance Model (Tam): Empirical Study of Bank Customers in Bekasi City. 2011 International Conference on Innovation, Management and Service, 14, pp. 345-436.

Meena, R. (2013). Green banking: As initiative for sustainable development. Global Journal of Management and Business Studies, 3(10), 1181-1186.

Morteza, G., Aranda, D., \& Amado, J. (2011). Adoption of E-Commerce in SMEs. Industrial Management \& Data, $111(8), 1238-1269$.

Nath, V., Nayak, N., \& Goel, A. (2014). Green banking practices - A review. IMPACT: International Journal of Research in Business Management (IMPACT: IJRBM), Vol 2(4), 45-62.

Nisha, N., Idrish, S. and Hossain, M.Z. (2015) 'Consumer acceptance and mobile banking services in Bangladesh', in Mohammad, Z.H. (Ed.): Green Banking in Bangladesh and Beyond, Zaman Printing and Packaging, Dhaka, Bangladesh, pp.155-182.

Phichitchaisopa, N. and Naenna, T. (2013) 'Factors affecting the adoption of healthcare information technology', EXCLI Journal, Vol. 12, pp.413-436.

Rifat, Afrin \& Nisha, Nabila \& Iqbal, Mehree \& Suvittawatt, Adisak. (2016). The Role of Commercial Banks in Green Banking Adoption: A Bangladesh Perspective. International Journal of Green Economics. 10. $226-251$. 10.1504/IJGE.2016.10002862.

Sachs, J. D., Woo, W. T., Yoshino, N., \& Taghizadeh-Hesary, F. (2019). Why Is Green Finance Important?

Sahoo, P., \& Nayak, B. P. (2007). Green banking in India. The Indian Economic Journal, 55(3), 82-98.

Samad, G., \& Manzoor, R. (2011). Green growth: an environmental technology approach. The Pakistan Development Review, 471-490.

Ullah, M. M. (2013). Green Banking in Bangladesh-A comparative analysis. World Review of Business Research, 3(4), 74-83.

Venkatesh, V., Thong, J.Y.L. and Xin, X. (2012) 'Consumer acceptance and use of information technology: extending the unified theory of acceptance and use of technology’, MIS Quarterly, Vol. 36, No. 1, pp.157-178.

Wang, Y., \& Zhia, Q. (2016). The role of green finance in environmental protection:Two aspects of market mechanism and policies. Energy Procedia, 104, 311 - 316.

World energy outlook. (2009). Executive summary. International Energy Agency. 